\title{
Marketing Mix on Customer Loyalty at Coffee Shop in Bandung
}

\author{
Erlina', Daniel Hermawan ${ }^{2}$ \\ 1,2 Parahyangan Catholic University, Bandung \\ e-mail: erlinasuparman2@gmail.com ${ }^{1}$, daniel.hermawan@unpar.ac.id²
}

To cite this document :

Erlina, E., \& Hermawan, D. (2021). Marketing Mix on Customer Loyalty at Coffee Shop in Bandung. Aptisi Transactions on Management (ATM), 5(1), 89-96.

DOI :

https://doi.org/10.33050/atm.v5i1.1488

\section{Abstract}

Coffee shop business growing rapidly in Bandung. Not just enjoying a cup of coffee, coffee shops are now transformed into places to socialize and gather together with friends and relatives. This trend makes existing coffee shops compete with one another by providing differentiation in product, price, place, promotion, service, atmosphere, and presentation process. This research tries to explore the marketing mix at coffee shop in Bandung and its effect on customer loyalty. With quantitative research methods taken from 80 respondents, it is known that the physical evidence factor is the main factor, on the other hand the price factor is the lowest factor that has impact on customer loyalty. This research underlines the importance of the components of the marketing mix in order to increase customer loyalty in the coffee shop business.

Keywords: coffee shop, customer loyalty, marketing mix, physical evidence, price

\section{Introduction}

Today, people's needs are increasingly diverse. This can be seen in the lifestyle changes experienced by people, especially in big cities. These lifestyle changes provide opportunities for business to provide products/services in accordance with the needs of the community. Changes in the lifestyle of urban communities have a significant influence on the development of the culinary world. The Ministry of Industry noted that throughout 2018, the food and beverage industry grew by 7.91 percent or exceeding national economic growth at 5.17 percent [1].

Coffee has also become a beverage trend since 2014 [2]. For urban communities, drinking coffee is no longer a necessity, but has developed into a lifestyle. This lifestyle makes people often come to cafes to just chat with friends, do work together, drink coffee, or do other things.

The development of cafes in Bandung has also led to fierce business competition among café business. This can be seen from the innovations made in the form of various concepts, unique names, delicious flavors, and various other innovations. The number of cafes in Indonesia, especially in Bandung, certainly answers the needs of consumers, both in terms of concept, food needs, and so on. Business are required to provide the best product, quality, price, service, atmosphere, location, or promotion to consumers. One of the main factors for companies to be able to attract consumer interest is to implement a good marketing strategy.

One of the marketing strategies that can be done to achieve company goals is to apply the concept of marketing mix. Marketing mix is a tool for companies to shape the characteristics of the products or services offered to customers. The concept of the marketing mix traditionally consists of the 4Ps, namely product, price, place, and promotion. The concept was later expanded to 7Ps with the addition of people, physical evidence, and process. The marketing mix concept is important for companies to increasing customer satisfaction and loyalty [3].

In a business context, customer loyalty is an important factor for the company to survive and even grow [4]. In the business world, it can be said that customers are considered the key to 
the success of a business. Having loyal customers is the main goal for business. No wonder the company will always provide the best for its consumers.

Along with the times, human needs are also increasingly diverse. To meet all these needs, business must be able to provide the best product or service possible. Consumers are also increasingly selective in deciding to make purchases. Many factors can affect customer loyalty to a product. Even though it looks simple, the marketing mix concept is able to create customer loyalty. With the marketing mix concept, it is hoped that business people will be able to manage their strategy well, so that they can increase profitability [5].

One of the studies conducted by Sylvia Tjan entitled "The Impact of Marketing Mix On Customer Loyalty Towards Plaza Indonesia Shopping Center" discusses the effect of the marketing mix on customer loyalty at Plaza Indonesia. Based on these results, there are 3 points in the 4Ps marketing mix that have a significant effect on customer loyalty. Significantly, product, place, and promotion have influence on customer loyalty at Plaza Indonesia. This proves that the marketing mix affects customer loyalty [6].

Another studies state the importance of marketing-mix variables on companies' revenues and value growth has been empirically demonstrated in consumer goods industries. A company's marketing mix decisions may depend on various generic factors (e.g. business model and goals, competition, the product life cycle, etc.). The marketing efforts and activities corresponding to the marketing mix elements, when combined and implemented adequately, are positively associated with financial and operational business performance in the lodging sector [7].

In addition, another study conducted by Tantra B. \& Marcelina [8] concluded that there are 5 elements of 7Ps that influence purchasing decisions at guest houses in Surabaya. The five elements are price, promotion, place, people, and physical evidence. However, the element that most influences the purchase decision is price.

Establishing a loyal customer base is an important goal for any industry and so they put considerable efforts into understanding which elements in marketing mix have a significant impact on customer loyalty. Oliver defines customer loyalty as a deeply held commitment to rebuy or repatronize a preferred product/service consistently in the future, thereby causing repetitive samebrand or same brand-set purchasing despite situational influences and marketing efforts having the potential to cause switching behavior [9]. Having loyal customers is a key for a business and required option for various companies based on its important role in creating sustainable competitive advantages [10].

\section{Marketing Mix}

Marketing mix describes the tools used by management that can affect sales. This tool can be used as a long-term or short-term strategy. Marketing mix is defined as a basic concept in modern marketing theory that can significantly attract customer interest [11]. Another definition states that a marketing mix is a combination of several marketing elements in order to meet consumer needs and expectations. Another goal is as a means for companies to build good relationships with their customers. Marketing mix activities constitute firm capabilities through which businesses transform available resources into valuable outputs and enabling them to deliver superior financial performance and enhance competitive advantages.

The marketing mix traditionally consists of the 4Ps, namely product, price, place and promotion. In the 4Ps marketing mix, usually the four elements are used for product oriented only. Then it developed and expanded from 4Ps to 7Ps consisting of product, price, place, promotion, people, physical evidence, and process. The 7Ps marketing mix concept is usually used when referring to services. The goal is to create customer-oriented services so that they can gain a sustainable competitive advantage. All elements in the marketing mix are interconnected in order to achieve company goals. Marketing mix is considered as a solution to problems in the marketing field. So, understanding the marketing mix conceptually is important for business practitioners before deciding to enter the market [12]. Marketing mix decisions in service firms are pivotal to build customer relationships and attain business objectives. Until now, marketing mix is still evolving and developing according to needs [13].

Marketing mix allows a business to make profitable marketing decisions at every level. 7P marketing mix strategy can provide company outcomes as an input in the future. For a business to be successful, it is important tool to pays attention of each element in marketing mix [14].

ATM Vol 5 No.1 January $2021: 89-96$ 


\section{Customer Loyalty}

Customer loyalty can be interpreted as taking sides with a particular product/service from time to time. Loyalty refers to the highest level of acceptance of a brand by customers, which is usually seen in customer buying behavior. Customer loyalty tends to be closer to the attitudes and behavior of consumers. Loyal customers can be measured through purchasing attitudes or behaviors, such as purchasing levels and recommending the brand to others. When a person is a loyal customer, he or she will exhibit buying behavior which is defined as non-random purchases. Customer loyalty can also be interpreted as continuous positive buying behavior from customers for certain brands or products. This can be influenced by customer satisfaction [15].

Nowadays, customer loyalty is becoming increasingly important. Many organizations adopt marketing mix focused on delivering customer satisfaction, believing that customer satisfaction gives rise to customer loyalty and increased profitability [16]. Customer loyalty emphasize that loyalty is a feature of people, rather than something inherent in brands [17]. Therefore, loyal consumers are considered an asset to an organization. From the behavioral perceptive, customer loyalty can be understood as the frequency of using particular services in a specific category compared with the total services. While, the attitudinal perspective, customer loyalty can be understood as customer tendency to do a relationship with a service provider [18].

Table 1. Previous Research [11], [15], [19], [20]

\begin{tabular}{|c|c|c|c|c|}
\hline Title & $\begin{array}{l}\text { Product } \\
\text { involvement, price } \\
\text { perceptions, and } \\
\text { brand loyalty }\end{array}$ & $\begin{array}{l}\text { Physician } \\
\text { Perceived Value as } \\
\text { a Mediating } \\
\text { Variable between } \\
\text { Marketing Mix } \\
\text { Strategy and } \\
\text { Physician } \\
\text { Satisfaction }\end{array}$ & $\begin{array}{l}\text { The Effects on } \\
\text { Customer } \\
\text { Satisfaction and } \\
\text { Customer Loyalty } \\
\text { by Integrating } \\
\text { Marketing } \\
\text { Communication } \\
\text { and After Sale } \\
\text { Service into The } \\
\text { Traditional } \\
\text { Marketing Mix } \\
\text { Model of Umrah } \\
\text { Travel Services in } \\
\text { Malaysia }\end{array}$ & $\begin{array}{l}\text { Long Live the } \\
\text { Marketing Mix. } \\
\text { Testing the } \\
\text { Effectiveness of the } \\
\text { Commercial } \\
\text { Marketing Mix in a } \\
\text { Social Marketing } \\
\text { Context }\end{array}$ \\
\hline Author(s) & $\begin{array}{l}\text { Alcina G. Ferreira } \\
\text { and Filipe J. } \\
\text { Coelho }\end{array}$ & $\begin{array}{l}\text { Mohsen Ali } \\
\text { Murshid, Zurina } \\
\text { Mohaidin, Goh Yen } \\
\text { Nee, and Yudi } \\
\text { Fernando } \\
\end{array}$ & $\begin{array}{l}\text { Othman, Harun, De } \\
\text { Almeida, and Sadg }\end{array}$ & $\begin{array}{l}\text { Ville Lahtinen, } \\
\text { Timo Dietrich, and } \\
\text { Sharyn Rundle- } \\
\text { Thiele }\end{array}$ \\
\hline Year & 2015 & 2016 & 2020 & 2020 \\
\hline Aim & $\begin{array}{l}\text { Knowing the effect } \\
\text { of product } \\
\text { involvement on } \\
\text { brand loyalty } \\
\text { which is partly } \\
\text { mediated by price } \\
\text { perceptions. }\end{array}$ & $\begin{array}{l}\text { Investigated the } \\
\text { mediating effect of } \\
\text { physicians' } \\
\text { perceived value on } \\
\text { the relationship } \\
\text { between marketing } \\
\text { mix strategies and } \\
\text { physician } \\
\text { satisfaction. }\end{array}$ & $\begin{array}{l}\text { Determine } \\
\text { effect of the } \\
\text { marketing mix on } \\
\text { customer } \\
\text { satisfaction and } \\
\text { loyalty to Umrah } \\
\text { travel agents in } \\
\text { Malaysia. }\end{array}$ & $\begin{array}{l}\text { Find out whether } \\
\text { the 4Ps in the } \\
\text { marketing mix are } \\
\text { more effective in } \\
\text { increasing } \\
\text { vegetable and fruit } \\
\text { intake compared to } \\
\text { campaigns that use } \\
\text { promotion only. }\end{array}$ \\
\hline Variables & $\begin{array}{l}\text { Product } \\
\text { involvement, price } \\
\text { perceptions, and } \\
\text { brand loyalty }\end{array}$ & $\begin{array}{ll}\begin{array}{l}\text { Marketing } \\
\text { strategy }\end{array} & \text { mix } \\
\text { physician } & \text { and } \\
\text { satisfaction } & \\
\end{array}$ & $\begin{array}{l}\text { Marketing mix and } \\
\text { customer loyalty }\end{array}$ & $\begin{array}{l}\text { Marketing mix and } \\
\text { social marketing }\end{array}$ \\
\hline Methods & Quantitative & Quantitative & Quantitative & Quantitative \\
\hline Result & $\begin{array}{l}\text { The effect of } \\
\text { product } \\
\text { involvement is } \\
\text { partly mediated by } \\
\text { price perceptions. } \\
\text { The product-brand } \\
\text { engagement }\end{array}$ & $\begin{array}{l}\text { There is a } \\
\text { significant and } \\
\text { positive } \\
\text { relationship } \\
\text { between product, } \\
\text { price, place, and } \\
\text { promotion on }\end{array}$ & $\begin{array}{l}\text { Marketing mix has a } \\
\text { positive effect on } \\
\text { customer loyalty } \\
\text { through customer } \\
\text { satisfaction, both } \\
\text { directly and }\end{array}$ & $\begin{array}{l}\text { The 4Ps approach } \\
\text { was more effective } \\
\text { and demonstrated } \\
\text { a significant } \\
\text { increase in fruit and } \\
\text { vegetable intake at } \\
\text { breakfast }\end{array}$ \\
\hline
\end{tabular}




\begin{tabular}{|l|l|l|l|l|}
\hline & $\begin{array}{l}\text { relationship was } \\
\text { only observed for } \\
\text { products with } \\
\text { lower involvement. }\end{array}$ & $\begin{array}{l}\text { doctor's } \\
\text { satisfaction. Price } \\
\text { and place are the } \\
\text { most influential } \\
\text { predictors of doctor } \\
\text { satisfaction. }\end{array}$ & $\begin{array}{l}\text { indirectly for Umrah } \\
\text { services. }\end{array}$ & $\begin{array}{l}\text { compared } \\
\text { campaigns using } \\
\text { promotional } \\
\text { strategies alone. }\end{array}$ \\
\hline
\end{tabular}

We want analyze the factors in marketing mix that can affect customer loyalty at Kopi Q.

Based on problem identification, the hypothesis that can be taken as follows:

HO: There is no effect of the marketing mix on customer loyalty at Kopi $Q$

H1: The marketing mix influences customer loyalty at Kopi $Q$

\section{Research Method}

In the first part, the research identification will be carried out. The research design process begins with the preparation of problem identification. The aim is to define the problem and scope of the research. Followed by the preparation of the background to the problem, research objectives, and research benefits. Then proceed with a literature review that discusses the theory of variables, previous research results, and research hypotheses.

In the second part, the research implementation process will be carried out. This section begins with the preparation of a research method consisting of a research design, population and sample, measurement and research instruments, data collection, and data analysis.

In the third stage, a research report was written. The results and discussion of the research will be compiled to discuss in-depth detail the marketing mix relationship to customer loyalty of Kopi Q. Closed with conclusions and suggestions from the research results.

Table 2. Research Design

\begin{tabular}{|c|l|}
\hline Phase & \multicolumn{1}{c|}{ Activity } \\
\hline Research Identification & - Problem identification \\
& - Determining research objectives \\
& - Literature review \\
& - Defining hypotheses \\
\hline Research Implementation & - Determining research methodology \\
& - Determining research measurement and instruments \\
& - Data collection \\
& - Data analysis \\
\hline Research Writing & - Research result and discussion \\
& - Summarize research by giving conclusion and suggestion \\
\hline
\end{tabular}

Kopi $Q$ was chosen because this coffee shop is well established since 2012. In addition, this coffee shop is still fulfilled by visitors during the COVID-19 pandemic, so we are interested to explore further the keys success of Kopi $Q$, in this study focused on marketing mix and customer loyalty.

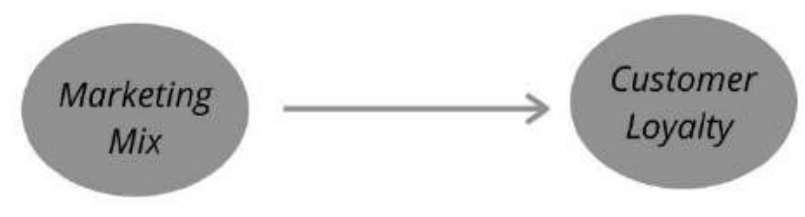

Figure 1. Research Model

We use quantitative methods with purposive data collection techniques. Purposive data collection was selected to fit the criteria for the research topic in determining suitable respondents [21]. Data were collected through questionnaires and processed using SPSS software to get an overview of the influence of the marketing mix on customer loyalty at Kopi $Q$. The sample in this study are 80 respondents. Respondents are customers who have visited and purchased products from Kopi Q. 
All questions items used in the research questionnaire are valid and reliable, so that can provide a complete picture of the marketing mix and customer loyalty at Kopi Q.

\section{Results and Analysis}

Based on the research results, Table 3 shows the respondent's demographic profile data.

Table 3. Respondent Demographic Profile

\begin{tabular}{|c|c|c|c|}
\hline Demographic Variables & Items & $\mathbf{n}$ & $\%$ \\
\hline Sex & $\begin{array}{l}\text { Male } \\
\text { Female }\end{array}$ & $\begin{array}{l}39 \\
51\end{array}$ & $\begin{array}{l}43,33 \% \\
56,67 \%\end{array}$ \\
\hline Age & $\begin{array}{l}<15 \text { y.o } \\
15-24 \text { y.o } \\
25-40 \text { y.o } \\
41-60 \text { y.o } \\
>60 \text { y.o }\end{array}$ & $\begin{array}{c}2 \\
49 \\
16 \\
19 \\
4\end{array}$ & $\begin{array}{c}2,22 \% \\
54,55 \% \\
17,78 \% \\
21,22 \% \\
4,44 \%\end{array}$ \\
\hline Status & $\begin{array}{l}\text { Married } \\
\text { Single }\end{array}$ & $\begin{array}{l}31 \\
59 \\
\end{array}$ & $\begin{array}{l}34,44 \% \\
65,56 \% \\
\end{array}$ \\
\hline Profession & $\begin{array}{l}\text { Housewife } \\
\text { Student } \\
\text { Employee } \\
\text { Entrepreneur } \\
\text { Unemployment } \\
\end{array}$ & $\begin{array}{c}9 \\
41 \\
23 \\
14 \\
2 \\
\end{array}$ & $\begin{array}{c}10 \% \\
45,56 \% \\
25,56 \% \\
15,56 \% \\
2,22 \% \\
\end{array}$ \\
\hline Last education & $\begin{array}{l}\text { Junior High School } \\
\text { Senior High School } \\
\text { Bachelor } \\
\text { Master }\end{array}$ & $\begin{array}{c}4 \\
46 \\
36 \\
4\end{array}$ & $\begin{array}{c}4,44 \% \\
51,11 \% \\
40 \% \\
4,44 \% \\
\end{array}$ \\
\hline Income per month & $\begin{array}{l}<\operatorname{Rp} 1.000 .000 \\
\operatorname{Rp} 1.000 .000-\operatorname{Rp} 2.000 .000 \\
\operatorname{Rp} 2.000 .000-\operatorname{Rp} 5.000 .000 \\
\operatorname{Rp} 5.000 .000-\operatorname{Rp} 10.000 .000 \\
>\operatorname{Rp} 10.000 .000\end{array}$ & $\begin{array}{l}15 \\
20 \\
27 \\
17 \\
11\end{array}$ & $\begin{array}{c}16,67 \% \\
22,22 \% \\
30 \% \\
18,89 \% \\
12,22 \%\end{array}$ \\
\hline Expense per month & $\begin{array}{l}<\operatorname{Rp} 1.000 .000 \\
\operatorname{Rp} 1.000 .000-\operatorname{Rp} 2.000 .000 \\
\operatorname{Rp} 2.000 .000-\operatorname{Rp} 5.000 .000 \\
\operatorname{Rp} 5.000 .000-\operatorname{Rp} 10.000 .000 \\
>\operatorname{Rp} 10.000 .000\end{array}$ & $\begin{array}{l}26 \\
30 \\
21 \\
7 \\
6\end{array}$ & $\begin{array}{l}28,89 \% \\
33,33 \% \\
23,33 \% \\
7,78 \% \\
6,67 \%\end{array}$ \\
\hline Total visit per 3 months & $\begin{array}{l}1 \text { times } \\
2-3 \text { times } \\
4 \text { times } \\
>5 \text { times } \\
\end{array}$ & $\begin{array}{c}40 \\
32 \\
10 \\
8 \\
\end{array}$ & $\begin{array}{l}44,44 \% \\
35,56 \% \\
11,11 \% \\
8,89 \% \\
\end{array}$ \\
\hline
\end{tabular}

Kopi Q customers are dominated by women (56.67\%), aged $15-24$ years old $(54.55 \%)$, single $(65.56 \%)$, work as students $(45.56 \%)$, have Senior High School level of education (51.11\%), has an income per month of Rp 2,000,000 - Rp 5,000,000 (30\%), has an expense of Rp 1,000,000 - Rp 2,000,000 (33.33\%).

Table 4. Research Indicators

\begin{tabular}{|c|c|c|c|}
\hline Variables & Mean & Corrected Item-Total Correlation & Cronbach Alpha \\
\hline P1 & 4,36 & 0,610 & 0,923 \\
\hline P2 & 4,19 & 0,439 & 0,925 \\
\hline P3 & 4,08 & 0,453 & 0,925 \\
\hline P4 & 4,29 & 0,467 & 0,924 \\
\hline P5 & 4,4 & 0,587 & 0,923 \\
\hline P6 & 4,31 & 0,659 & 0,922 \\
\hline H1 & 3,93 & 0,402 & 0,925 \\
\hline H2 & 3,6 & 0,369 & 0,926 \\
\hline PL1 & 3,72 & 0,298 & 0,928 \\
\hline
\end{tabular}




\begin{tabular}{|c|c|c|c|}
\hline PL2 & 4,02 & 0,588 & 0,923 \\
\hline PL3 & 4,26 & 0,546 & 0,923 \\
\hline PR1 & 4,08 & 0,636 & 0,922 \\
\hline PR2 & 4,14 & 0,615 & 0,923 \\
\hline PR3 & 3,96 & 0,426 & 0,925 \\
\hline PR4 & 3,93 & 0,605 & 0,923 \\
\hline O1 & 4.29 & 0,653 & 0,922 \\
\hline O2 & 4,32 & 0,700 & 0,922 \\
\hline T1 & 4,36 & 0,512 & 0,924 \\
\hline T2 & 4,56 & 0,661 & 0,922 \\
\hline T3 & 4,65 & 0,533 & 0,924 \\
\hline T4 & 4,46 & 0,396 & 0,925 \\
\hline T5 & 4,36 & 0,575 & 0,923 \\
\hline PO1 & 4,39 & 0,616 & 0,922 \\
\hline PO2 & 4,39 & 0,639 & 0,922 \\
\hline PO3 & 4,21 & 0,614 & 0,922 \\
\hline L1 & 4,39 & 0,523 & 0,924 \\
\hline L2 & 3,91 & 0,540 & 0,925 \\
\hline L3 & 3,44 & 0,455 & 0,925 \\
\hline L4 & 3,93 & 0,476 & 0,925 \\
\hline L5 & 4,2 & 0,560 & 0,923 \\
\hline
\end{tabular}

Notes: P (Product); H (Price); PL (Place); PR (Promotion); O (People); T (Physical Evidence); PO (Process); L (Customer Loyalty)

Based on marketing mix indicators, T3 has the highest score when compared to other indicators. Meanwhile, the $\mathrm{H} 2$ indicator has the lowest score. The research indicator T3 talks about "the atmosphere of the Kopi Q room is comfortable" representing physical evidence, while the research indicator $\mathrm{H} 2$ underlines "Kopi Q products have an affordable price" representing price. Meanwhile, from the customer loyalty indicator, L1 made a large contribution, namely "I believe in the quality of Kopi Q products" and the lowest on the L3 indicator with the statement "I will not switch to another restaurant/café".

\section{Simple Linear Regression Analysis Test}

Table 5. Simple Linear Regression Analysis Test

Coefficients $^{a}$

\begin{tabular}{|c|c|c|c|c|c|}
\hline \multirow[b]{2}{*}{ Model } & \multicolumn{2}{|c|}{ Unstandardized Coefficients } & \multirow{2}{*}{$\begin{array}{c}\begin{array}{c}\text { Standardized } \\
\text { Coefficients }\end{array} \\
\text { Beta } \\
\end{array}$} & \multirow[b]{2}{*}{$\mathrm{t}$} & \multirow[b]{2}{*}{ Sig. } \\
\hline & $B$ & Std. Error & & & \\
\hline $\begin{array}{ll}1 & \text { (Constant) } \\
& \text { LP }\end{array}$ & $\begin{array}{r}2.608 \\
.406\end{array}$ & $\begin{array}{l}.199 \\
.051\end{array}$ & 649 & $\begin{array}{r}13.088 \\
8.008\end{array}$ & $\begin{array}{l}.000 \\
.000\end{array}$ \\
\hline
\end{tabular}

a. Dependent Variable: MX

The general equation for simple linear regression is

$$
\begin{gathered}
Y=\alpha+\beta x \\
Y=2.608+0,406 x
\end{gathered}
$$

The value of $\alpha$ is a constant number in the unstandardized coefficient 2.608, which means that if there is no customer loyalty, the consistent value of the marketing mix $(X)$ is 26,608 . whereas, the value of $b$ is the number of regression coefficients. A figure of 0.406 means that for every 1-point increase in customer loyalty $(Y)$, the marketing mix $(X)$ will increase by 0.406 . Results Sig. obtained is 0.000 and is smaller than the probability of 0.05 , so it can be concluded that $\mathrm{HO}$ is rejected, which means there is an effect of marketing mix $(\mathrm{X})$ on customer loyalty $(\mathrm{Y})$. 
T test

Tabel 6. T test

Coefficients $^{\mathrm{a}}$

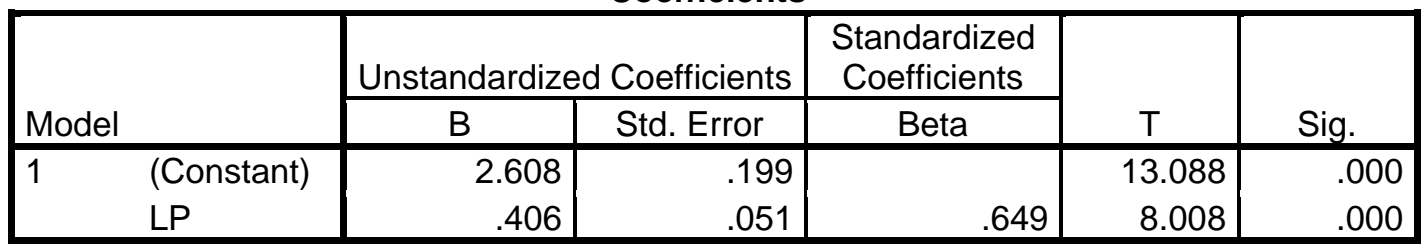

a. Dependent Variable: MX

Based on the resulting output, $\mathrm{t}$ count is 8,008 . Because $\mathrm{t}$ count is greater than $\mathrm{t}$ table, it can be concluded that $\mathrm{H} 0$ is rejected and $\mathrm{H} 1$ is accepted, which means that there is an effect of marketing mix on customer loyalty.

\section{Determination Coefficient Test}

Tabel 7. Determination Coefficient Test

Model Summary

\begin{tabular}{|l|c|r|r|r|}
\hline Model & $\mathrm{R}$ & $\mathrm{R}$ Square & \multicolumn{1}{c|}{$\begin{array}{c}\text { Adjusted R } \\
\text { Square }\end{array}$} & $\begin{array}{c}\text { Std. Error of } \\
\text { the Estimate }\end{array}$ \\
\hline 1 & $.649^{\mathrm{a}}$ & .422 & .415 & .33139413831 \\
& & & .4394 \\
\hline
\end{tabular}

a. Predictors: (Constant), LP

From the model summary results, it is known that the $R$ Square value is 0.422 . These results indicate that marketing mix has an influence on customer loyalty at Kopi $Q$ by $42.2 \%$. Meanwhile, $57.8 \%$ of customer loyalty at Kopi $Q$ is influenced by other variables that not analyzed.

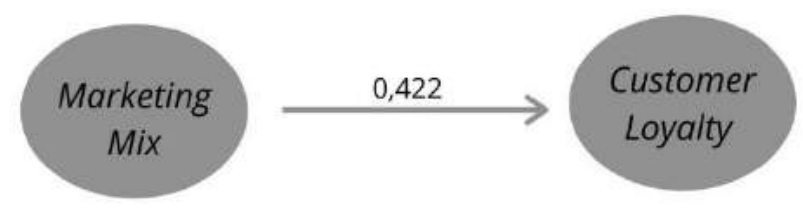

Figure 2. Influence of Marketing Mix on Customer Loyalty

\section{Conclusion}

Marketing mix proved impacted customer loyalty in certain points. Price have the lowest score. Djumarno, Anjani, \& Djamaluddin [22] also highlighted prices of products proven significant positive effect on customer loyalty. Kopi $Q$ need to be consider, since customers feel Kopi $Q$ not yet providing affordable prices. Kopi $Q$ can create promos with special prices, especially during weekdays or hours that are relatively quiet, so that customers that sensitive with price can visit at the specified time. Meanwhile, physical evidence has the highest score. This means that the atmosphere of the Kopi $Q$ provides comfort atmosphere through the cleanliness of a comfortable place. Thus, physical evidence contributes as a factor that can maintain and increase customer loyalty. This results also supported by Rachman [23] that physical evidence and assurance services have a positive and significant impact on customer satisfaction and customer loyalty.

To increase customer loyalty, Kopi Q can improve several strategies in marketing mix, especially in price. Promoting discounted prices or food and beverage packages at a more affordable price can be done to attract more customer interest in order. Also, this pricing strategy can create customer satisfaction and gain customer loyalty eventually. The comfort and cleanliness of Kopi $Q$ is one of the important factors that Kopi $Q$ must pay attention in order to maintain and increase customer loyalty. In addition, the procurement of loyalty cards in the form of stamps with minimum amount of purchase can be done by Kopi $Q$ to attract customers, so that 
they can continue to come and increase product consumption at Kopi Q. The quality of Kopi $Q$ products needs to be maintained and continuously improved to maintaining customer loyalty.

This research focusing on marketing mix and customer loyalty variables. For further research, this research can be develop by examining other variables that can affect customer loyalty, such as brand awareness and customer behavior. Also bring this research in other cities, such as Jakarta, Yogyakarta, Surabaya or to wider scale, such as West Java.

\section{References}

[1] K. RI, "kemenperin.go.id," 18 February 2019. [Online]. Available: https://kemenperin.go.id/artikel/20298/Industri-Makanan-dan-Minuman-Jadi-SektorKampiun-.

[2] A. A. Ikhsania, "lifestyle.okezone.com," 9 November 2017. [Online]. Available: https://lifestyle.okezone.com/read/2017/11/09/298/1811342/alasan-konsumsi-kopi-jaditren-gaya-hidup-masyarakat-urban.

[3] K. S. Al Badi, "The Impact of Marketing Mix on the Competitive Advantage of the SME Sector in the Al Buraimi Governorate in Oman," SAGE Open, pp. 1-10, 2018.

[4] N. Vilkaite-Vaitone dan I. Skackauskiene, "Service Customer Loyalty: An Evaluation Based on Loyalty Factors," Sustainability, vol. 12, pp. 1-20, 2020.

[5] M. Supriyanto dan M. Taali, "PENGARUH BAURAN PEMASARAN (MARKETING MIX) TERHADAP PENGAMBILAN KEPUTUSAN MENGINAP DI THE SUN HOTEL MADIUN," Epicheirisi. Volume 2 Nomor 1 Tahun 2018, pp. 14-17, 2018.

[6] S. Tjan, "The Impact of Marketing Mix On Customer Loyalty Towards Plaza Indonesia Shopping Center," iBuss Management Vol. 3, No. 2, (2015) 392-402, pp. 393-400, 2015.

[7] O. Cruz-Milan, "Hotels' marketing mix responses at insecurity-stricken destinations: a study in the US-Mexico border," Hotels' Marketing MIx Responses, p. 2, 2020.

[8] B. Tantra B dan J. Marcelina, "PENGARUH MARKETING MIX (7P) TERHADAP KEPUTUSAN PEMBELIAN PADA GUEST HOUSE DI SURABAYA," pp. 1-12, 2017.

[9] G. Dowling, M. D. Uncles dan K. Hammond, "Customer Loyalty and Customer Loyalty Program," Journal of Consumer Marketing · July 2003, pp. 5-7, 2003.

[10] A. S. Abu-Alhaija, R. N. Raja Yusof, H. Hashim dan N. S. Jaharuddin, "Determinants of Customer Loyalty: A Review and Future Directions," Australian Journal of Basic and Applied Sciences, pp. 106-107, 2018.

[11] M. A. Murshid, Z. Mohaidin, G. Y. Nee dan Y. Fernando, "Physician perceived value as a mediating variable between marketing mix strategy and physician satisfaction," Asia Pacific Journal of Marketing and Logistics Vol. 28 No. 5, 2016, pp. 780-797, 2016.

[12] D. R. Abubakar, Manajemen Pemasaran, Bandung: Alfabeta, 2017.

[13] B. A. Othman, A. Harun, N. M. De Almeida dan Z. M. Sadg, "fsad," Umrah travel services in Malaysia, pp. 1-20, 2020.

[14] V. Paurova dan M. Nadanyiova, "MARKETING MIX AS PART OF MARKETING STRATEGY USED IN THE SERVICE INDUSTRIES," 55th International Scientific Conference on Economic and Social Development - Baku, 18-19 June, 2020, pp. 652-655, 2020.

[15] B. A. Othman, A. Harun, N. M. D. Almeida dan Z. M. Sadq, "The effects on customer satisfaction and customer loyalty by integrating marketing communication and after sale service into the traditional marketingmix model of Umrah travel services in Malaysia," Journal of Islamic Marketing, 2020.

[16] N. J. Slack dan G. Singh, "The effect of service quality on customer satisfaction and loyalty and the mediating role of customer satisfaction," Service quality in supermarket sector, pp. 544-546, 2019.

[17] G. R. Dowling dan K. Hammond, "Customer Loyalty and Customer Loyalty Programs," Journal of Consumer Marketing · July 2003, pp. 5-20, 2003. 
[18] A. Shankar dan C. Jebarajakirthy, "The influence of e-banking service quality on customer loyalty," Influence of EBSQ on customer loyalty, pp. 1121-1133, 2018.

[19] A. G. Ferreira dan F. J. Coelho, "Product involvement, price perceptions, and brand loyalty," Journal of Product \& Brand Management, pp. 349-360, 2015.

[20] V. Lahtinen, T. Dietrich dan S. Rundle-Thiele, "Long live the marketing mix. Testing the effectiveness of the commercial marketing mix in a social marketing context," Long live the, pp. 357-372, 2019.

[21] M. Pradana dan A. Reventiary , "PENGARUH ATRIBUT PRODUK TERHADAP KEPUTUSAN PEMBELIAN SEPATU MEREK CUSTOMADE (STUDI di MEREK DAGANG CUSTOMADE INDONESIA)," JURNAL MANAJEMEN VOL. 6 NO. 1 JUNI 2016 , pp. 1-10, 2016.

[22] D. Djumarno, S. Anjani dan S. Djamaluddin, "Effect of Product Quality and Price on Customer Loyalty through Customer Satisfaction," International Journal of Business and Management Invention (IJBMI) Volume 7 Issue 8 Ver. I, pp. 13-20, 2018.

[23] A. Rachman, "Analysis of Effect of Physical Evidence and Service Assurance on Customer Satisfaction and Customer Loyalty in using Car Rental Service (PT Pusaka Prima Transport Cases)," dalam IOP Conference Series: Materials Science and Engineering, Bandung, 2017. 